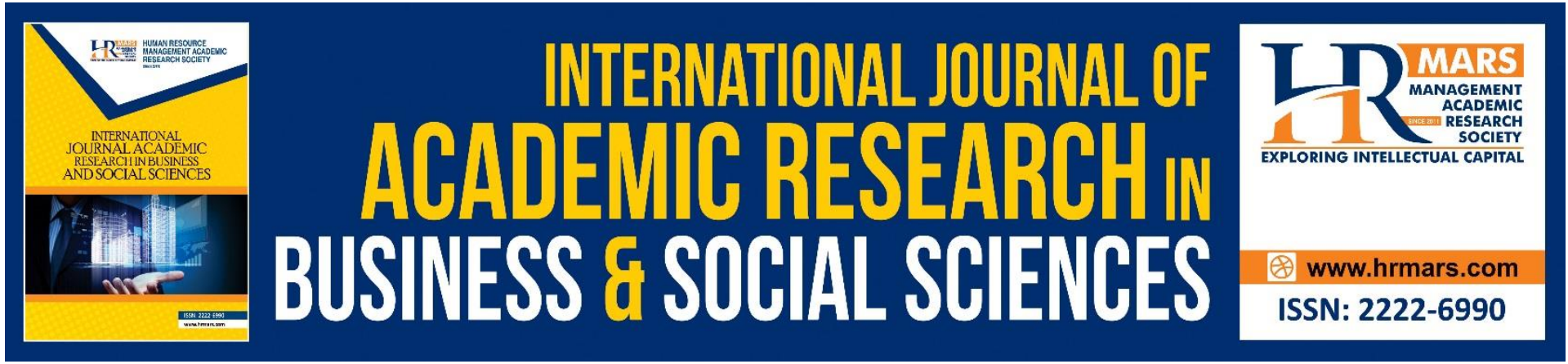

\title{
Sustainability of E-Hailing Services: The Roles of Job Preferences, Competency and Resilience
}

Azimah Daud, Zaimy Johana Johan, Ainie Hairianie Aluwi, Muhammad Khalil Omar

To Link this Article: http://dx.doi.org/10.6007/IJARBSS/v11-i6/10214 DOI:10.6007/IJARBSS/v11-i6/10214

Received: 16 April 2021, Revised: 21 May 2021, Accepted: 02 June 2021

Published Online: 19 June 2021

In-Text Citation: (Daud et al., 2021)

To Cite this Article: Daud, A., Johan, Z. J., Aluwi, A. H., \& Omar, M. K. (2021). Sustainability of E-Hailing Services: The Roles of Job Preferences, Competency and Resilience. International Journal of Academic Research in Business and Social Sciences, 11(6), 838-846.

Copyright: (c) 2021 The Author(s)

Published by Human Resource Management Academic Research Society (www.hrmars.com)

This article is published under the Creative Commons Attribution (CC BY 4.0) license. Anyone may reproduce, distribute, translate and create derivative works of this article (for both commercial and non-commercial purposes), subject to full attribution to the original publication and authors. The full terms of this license may be seen at: http://creativecommons.org/licences/by/4.0/legalcode

Vol. 11, No. 6, 2021, Pg. 838- 846

http://hrmars.com/index.php/pages/detail/IJARBSS

JOURNAL HOMEPAGE

Full Terms \& Conditions of access and use can be found at http://hrmars.com/index.php/pages/detail/publication-ethics 


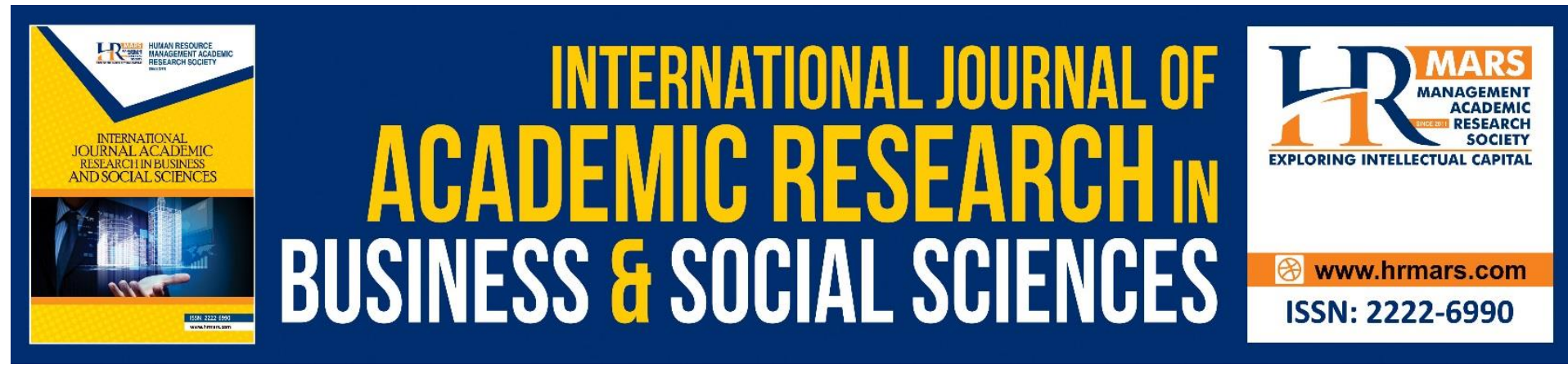

\title{
Sustainability of E-Hailing Services: The Roles of Job Preferences, Competency and Resilience
}

\author{
Azimah Daud, Zaimy Johana Johan, Ainie Hairianie Aluwi, \\ Muhammad Khalil Omar \\ Faculty of Business and Management, Universiti Teknologi MARA Cawangan Selangor, \\ 42300 Bandar Puncak Alam, Selangor, Malaysia
}

\begin{abstract}
Malaysian government have provided several economic incentives since 2017 to promote jobs in e-hailing industry. Based on the current knowledge, it is apparent that there is lack of studies in determining the realistic attributes and overall specification of e-hailing jobs. This quantitative study explores the antecedents of e-hailing jobs' sustainability. It describes the motivations of individual's appeals in particular from B40 segments for e-hailing jobs in Malaysia. This study explores three perspectives of service sustainability in terms of job preferences, competency and resilience among 397 e-hailing drivers in major cities of Malaysia. Additionally, this study provides considerable evidence from the supply side of ehailing service provision especially with respect to the motives of becoming a e-hailing driver. The results identified job preferences and competency as significant predictors for e-hailing service sustainability, while job resilience is not significant. These findings may help e-hailing companies to better understand what drivers look for in their employment. Additionally, this study provides insight for individuals who are currently considering becoming e-hailing drivers in the promising and ever evolving e-hailing services.
\end{abstract}

Keywords: E-Hailing, E-hailing, Services Adoption, Operational Characteristics, Alternative Travel Modes Preference

\section{Introduction}

The advent of e-hailing services since 2012, has created new interest among the Malaysian community to take part in the changing pattern of labour market thus e-hailing driver becomes one of the most common jobs in Malaysia. As of 2019, there were about 160,000 ridesharing drivers employed for this job (Department of Statistics, 2020). Attributable to extra income potential and accessible employment opportunity, Malaysian government have provided several economic incentives since 2017 to promote jobs in e-hailing industry. Incentives include cash aid for car ownership for the purpose of becoming drivers for eligible citizens and the recent incentives in Pelan Jana Semula Ekonomi Negara (Penjana) 2021 package worth RM75 million, RM50 million for Gig Economy stages and RM25 million for Malaysia Digital Economy Corporation (MDEC) Global Online Workforce (GLOW) programs aim to improve the livelihood, social security and welfare of e-hailing drivers. These economic initiatives were expected to further motivate the uptake of e-hailing jobs and improve the 
socio-economic status of unemployed citizens and Malaysian B40 segment. In recent efforts, research related to e-hailing have mainly done in the areas of demand side such as user's preferences (Wang et al., 2020), service quality (Azudin et al., 2018), matching algorithm (Peng et al., 2020), safety aspects of e-hailing use (Meshram et al., 2020), governance (Jais \& Marzuki, 2020). Based on the current knowledge, it is apparent that there is lack of studies in determining the realistic attributes and overall specification of e-hailing jobs. This study contends that there is a need to explore the motives of becoming an e-hailing driver and further develop a specification model for this job. It also aims to determine the antecedents behind e-hailing job by analysing three variables namely job preferences, job competency and job resilience in a single framework in order to offer a comprehensive understanding of ehailing service sustainability.

\section{Literature Review \\ Job Sustainability}

Sustainability are widely discussed in career literature (Valcour, 2015; McDonald \& Hite, 2018). Various definitions were found in the literature. Job sustainability is concerned with empowering young people to the concept of helping them to continue to be employed individual with a career (Knockaert \& Maillefert, 2004). A sustainable job continuity over time can be encouged by combining the efforts of the working individuals themselves and all policy makers and stakeholders involving in career environment (Rapuano, 2020). An individual act as a main career player that has to be responsible for their own career and get involved in career self-management in order to build job sustainability. By focusing on a life-long career path and developing self-competencies, a person will be more attractive, valuable and marketable in any career path they entered (Rapuano, 2020). A person will then able to achieve own satisfaction through any particular job they engaged with.

\section{Job Preferences}

Job preference is a concept used to explain the relationship between an individual and their work. Job or work preferences is the results of peoples' desire from their involvement in work. Job preference can influence person's career decisions and it is crucial determinants in their job motivation (Konrad, Ritchie, Lieb, \& Corrigall, 2000). According to research on e-hailing drivers' job preference, e-hailing drivers appear to be attracted to this profession largely because of the flexibility that the services offers and the earnings level per hour (Hall \& Krueger, 2016 \& Chen \& Sheldon, 2016). Apart from that, Shokoohyara (2018) performed analysis of ridesharing platforms from drivers' perspective and the study showed that ridesharing drivers consider job flexibility, work-life balance and availability to meet new people as the positive reasons of continuing to work in ridesharing platforms. Malin \& Chandler (2016) found the same results from their interviewed with ridesharing drivers whereby flexibility and sociability are the major reasons for drivers to involve with e-hailing platforms.

\section{Job Competencies}

Janis \& Ziaran (2017) defined job competency as a collection of knowledge, experiences, skills, abilities and other suitable characteristics that ensure effective performance at work. Competency measurement tend to be standardized but in reality, each and every position and job is unique and different thus, it presupposes different elements of assessment (Puteh, Kaliannan, \& Alam, 2016). According to Francis-Smythe et al (2013) job competencies act as 
a tool that facilitates in certain job performance. In the context of conducting a ehailing services, it is important for drivers to be competence. Shove, Pantzar, \& Watson (2012) proposed three-element of social practice framework which inlcudes competence as one of the element. According to Shove et al (2012) competence is defined as "multiple forms of understanding and knowledgeability". It encompasses an individuals' skills, know-how, educational knowledge and the provision of sufficient information. Cass \& Faulconbridge (2016) agreed that the adoption of sufficient competencies, information, understanding and knowledgeability is crucial elements for persons in deciding to use a specific type of transportation. Research by Bauer (2017) portrays that drivers for e-hailing services have to first understand the whole purpose and process involved in their work. It is crucial for drivers to have the know-how regarding the service ability of the e-hailing platforms.

\section{Job Resilience}

Job resilience is the capability of a person to absorb an unpleasant environment pertaining to their job. Job resilience also describes a person's ability to fulfil a highly pressured situation while performing certain task at work. In addition, a resilient worker is often featured by their continuous learning attitude, resilience to disagreeable occurrence and self-management at work (Ahmad et al., 2019). Finally, job resilience can be defined as (Naswall, Kuntz, Hodliffe, \& Malinen, 2015) an employee's capability to utilize resources at workplace even when facing challenging circumstances to support the organization's goals. Persons with great job resiliency proved to have a better focus on constant learning that enables them to compete in the global economy (Ahmad et al., 2019). A recent study performed by Mishra \& McDonald (2017) revealed that the development of job competency over the transition of time leads to employee resilient behavior. There are several evidences that caused the improvement of job resilience. It is related with several types of skills and competencies for example interpersonal and communication skills (Mansfield et al., 2012). Ahmad et al (2019) \& Mansfield et al (2012) found that job competency as a significant influence with job resilience. Research performed by Ahmad et al (2019) pertaining to found that the mediating roles of job resilience positively affected job competency.

\section{Methodology}

E-hailing drivers in few major cities in Malaysia have been selected for this study, and target respondents consist of both two and four wheelers' drivers. Purposive sampling was employed for this study as the sampling here was confined by specific types of people who can provide the desired information. The sample size calculation for this study was based on Tabachnick, Fidell, and Osterlind (2001), who recommended a five-to-one ratio for each item to be factor analysed. The questionnaires were distributed from August until November, 2020 through e-hailing associations in Malaysia focusing on the main cities, which are Klang valley, Penang, Johor Bahru, Pantai Timur (Kelantan, Terengganu, Pahang), and Borneo (Sabah and Sarawak). A total of 392 questionnaires collected but only 372 were usable for further analysis, where 20 questionnaires were removed due to straight lining. There were $80 \%$ male and $20 \%$ female respondents from both 2 and 4 wheelers, and $70 \%$ were graduates and $30 \%$ non-graduates. All items were answered by the respondents using a five-point Likert scale. Measurements were adapted from well-known works of literature, i.e. Poon, Briscoe, AbdulGhani \& Jones (2015) for job sustainability (4 items), Zhang, Bufquin and Lu (2019) for six dimensions of job preferences, namely financial (4 items), social (4 items), freedom and flexibility ( 4 items), easiness to operate ( 4 items), availability of resources ( 4 items) and 
excitement about the future (4 items), Bharwani and Jauhari (2013) for job competencies (10 items), and (Ahmad, Latif, Bilal, \& Hai, 2019) for job resilience (6 items).

Partial lease square (PLS), a variance-based approach to structural equation modeling (SEM) has been chosen to evaluate the research model. Decision to use PLS after assessing the multivariate skewness and kurtosis where the data we have collected was not multivariate normal and as suggested by to assess the multivariate skewness and kurtosis using the software at https://webpower.psychstat.org/models/kurtosis/results.php (Hair et al., 2017). The Mardia's multivariate skewness $(\beta=552.1683, \rho<0.01$ ) and Mardia's multivariate kurtosis $(\beta=2582.0182, \rho<0.01)$, therefore we proceeded with SmartPLS, which is a non-parametric analysis software.

\section{Findings and Discussion}

Two types of validity were being examined to assess the measurement model. First is the convergent validity and second is the discriminant validity. Table 1 indicates the summary of the convergent validity measurements which ascertained the loadings, average variance extracted (AVE), and composite reliability (CR). The standardized values of loadings recommended are greater than 0.708 and AVE should be greater than 0.5 (Fornell \& Larcker, David, 1981; Hair et al., 2017). However, researchers still maintain items with loadings in the range of 0.6 to 0.7 as $C R$ and $A V E$ are all above the trash hold values of 0.7 and 0.5 respectively.

Table 1: Summary result of the measurement constructs

\begin{tabular}{|c|c|c|c|c|c|}
\hline Variables & Loading & CA & thoA & CR & AVE \\
\hline \multicolumn{6}{|l|}{ Job Preferences (JP) } \\
\hline - $\quad$ JPFinancialG1 & 0.756 & 0.931 & 0.937 & 0.94 & 0.513 \\
\hline - $\quad$ JPFinancialG2 & 0.695 & & & & \\
\hline - JPFinancialG3 & 0.706 & & & & \\
\hline - JPSocialG3 & 0.606 & & & & \\
\hline - JPSocialG4 & 0.605 & & & & \\
\hline - JPEasy2 & 0.604 & & & & \\
\hline - JPEasy3 & 0.654 & & & & \\
\hline - JPEasy4 & 0.661 & & & & \\
\hline - JPResource1 & 0.735 & & & & \\
\hline - JPResource2 & 0.753 & & & & \\
\hline - JPResource3 & 0.722 & & & & \\
\hline - JPExcite1 & 0.789 & & & & \\
\hline - JPExcite2 & 0.716 & & & & \\
\hline - JPExcite3 & 0.823 & & & & \\
\hline - JPExcite4 & 0.811 & & & & \\
\hline Job Competencies (JC) & & 0.931 & 0.936 & 0.944 & 0.629 \\
\hline $\begin{array}{l}\text { Friendly } \\
\text { communication }\end{array}$ & 0.785 & & & & \\
\hline $\begin{array}{l}\text { - Work ethics and team } \\
\text { work }\end{array}$ & 0.723 & & & & \\
\hline $\begin{array}{ll}\text { - Interpersonal } \\
\text { customer service }\end{array}$ and & 0.822 & & & & \\
\hline
\end{tabular}




\begin{tabular}{|c|c|c|c|c|c|}
\hline $\begin{array}{l}\text { - Professionalism and } \\
\text { self-management }\end{array}$ & 0.818 & & & & \\
\hline $\begin{array}{l}\text { - Cultural sensitivity and } \\
\text { adaptability }\end{array}$ & 0.827 & & & & \\
\hline $\begin{array}{ll}\text { - Work } & \text { related } \\
\text { information } & \end{array}$ & 0.805 & & & & \\
\hline $\begin{array}{l}\text { Knowledge of and } \\
\text { compliance with legal } \\
\text { and regulatory }\end{array}$ & 0.795 & & & & \\
\hline $\begin{array}{l}\text { - Service Orientation } \\
\text { Attitude }\end{array}$ & 0.815 & & & & \\
\hline $\begin{array}{l}\text { Balance private and } \\
\text { work life }\end{array}$ & 0.727 & & & & \\
\hline - $\quad$ Pro-activeness & 0.809 & & & & \\
\hline Job Resilience (JR) & & 0.797 & 0.875 & 0.856 & 0.603 \\
\hline $\begin{array}{l}\text { - Risks associated with } \\
\text { the job }\end{array}$ & 0.643 & & & & \\
\hline $\begin{array}{l}\text { - Problems encountered } \\
\text { in the job }\end{array}$ & 0.819 & & & & \\
\hline $\begin{array}{l}\text { - Discomfort associated } \\
\text { with the job }\end{array}$ & 0.911 & & & & \\
\hline $\begin{array}{l}\text { - Survival in the job in } \\
\text { view of competition }\end{array}$ & 0.705 & & & & \\
\hline Job Sustainability (JS) & & 0.831 & 0.856 & 0.887 & 0.665 \\
\hline $\begin{array}{l}\text { - Satisfaction with the } \\
\text { job }\end{array}$ & 0.827 & & & & \\
\hline $\begin{array}{l}\text { Continue with the job } \\
\text { for the next few years }\end{array}$ & 0.863 & & & & \\
\hline $\begin{array}{l}\text { - Continue with the in } \\
\text { the retirement age }\end{array}$ & 0.881 & & & & \\
\hline $\begin{array}{l}\text { - Continue with the job } \\
\text { longer }\end{array}$ & 0.676 & & & & \\
\hline & & & & & \\
\hline
\end{tabular}

Note: Item JR4, JR6, JPSocial1, JPSocial2, JPSocial5, JPFF1, JPFF2, JPFF3, JPFF4, JPEasy1 were deleted due to low loadings

In testing the hypotheses, bootstrapping procedures were applied in finding the relationship between said variables. The overall results of predictors for job sustainability variables which are job preferences, resilient and competencies were discussed. Job preferences $(\beta=0.632$, $t=11.564, p<0.05)$ and job competencies $(\beta=0.125, t=2.216, p<0.05)$ are significant, while job resilient $(\beta=-0.002, t=0.044, p>0.05$,) was not significant. Thus, $\mathrm{H} 1$ and $\mathrm{H} 2$ are supported, while $\mathrm{H} 3$ is not supported. Overall, the $\mathrm{R}^{2}$ is 0.504 indicates that $50.4 \%$ of the variance in factors influencing job sustainability can be explained by all the independent variables. 
Table 2: Path Coefficient and significant findings

\begin{tabular}{llllll}
\hline $\begin{array}{l}\text { Hypothes } \\
\text { is }\end{array}$ & Std Beta & $\begin{array}{l}\text { t- } \\
\text { value }\end{array}$ & p-value Decision \\
\hline H1 & $\begin{array}{l}\text { Job preferences-- } \\
\rightarrow \text { Job sustainability } \\
\text { Job }\end{array}$ & 0.125 & 2.216 & 0.027 & Supported \\
H2 & 0.632 & 11.564 & 0 & Supported \\
& $\begin{array}{l}\text { competencies } \rightarrow \text { Job } \\
\text { sustainability } \\
\text { Job resilience- } \rightarrow \\
\text { Job sustainability }\end{array}$ & - & 0.044 & 0.965 & $\begin{array}{l}\text { Not } \\
\text { supported }\end{array}$ \\
\hline
\end{tabular}

\section{Discussion and Conclusion}

Jobs in e-hailing industry have been heralded as solution to the current economic and social issues. This study determines the realistic attributes and overall specification of ehailing jobs. This study uncovered the motives of becoming an e-hailing driver. Therefore, this study has theoretical and practical significance in terms of providing considerable evidence regarding the motives of individual to take part in the changing pattern of sharing economy in particular e-hailing services. As mentioned above, exploration on the supply side of ehailing is rather limited, therefore this study contributes to the literature by determining the antecedents behind e-hailing service offering. Second this study analyses the three variables of job preferences, job competency and job resilience in a single framework in order to offer a comprehensive understanding of motives that drivers may have in the delivery of e-hailing services. Furthermore, the quantitative findings of this study have provided empirical evidences for the development of e-hailing jobs. Previous studies mainly investigated on the demand side of service provision focusing on the users, rather than exploring the phenomenon from the perspective of supply side in particular drivers' aspect. From the practical standpoint findings from this study may help e-hailing companies to better understand what drivers look for in their employment. Additionally, this study provides insight for individuals who are currently considering becoming e-hailing drivers in the promising and ever evolving e-hailing services. The present study revealed the job specification model for e-hailing jobs that individual seek from their participation in the services provision. Using quantitative research approach several antecedents emerged from this investigation. This study revealed many significant antecedents of e-hailing service sustainability, however this study is not free from limitation. This study serves as exploratory in nature and sought to better understand the supply side of e-hailing service provision with the inclusion of three main antecedents. More research is needed to determine additional antecedents, in the proposed structural model.

\section{Acknowledgement}

This research is funded by the Fundamental Research Grant Scheme (600-IRMI/DANA 5/3/BESTARI (P) (031/2018) from Universiti Teknologi MARA, Bandar Puncak Alam, Selangor, Malaysia.

\section{Corresponding Authors}

Muhamad Khalil Omar, Faculty of Business and Management, Universiti Teknologi MARA Cawangan Selangor, 42300 Bandar Puncak Alam, Selangor, Malaysia.

Email:khalil.omar@uitm.edu.my 


\section{References}

Department of Statistics Malaysia. (2020). Key Statistics of Labour Force in Malaysia. Malaysia: Department of Statistics Malaysia Official Portal.

Wang, Y., Wang, S., Wang, J., Wei, J., \& Wang, C. (2020) An empirical study of consumers' intention to use ride-sharing services: using an extended technology acceptance model, Transportation (Amst)., vol. 47, no. 1, doi: 10.1007/s11116-018-9893-4.

Azudin, N., Norhashim, M., \& Nachiappan, G. (2018) Service quality of uber in a small city: a case study of Ipoh uber drivers, J. Adv. Res. Business, Mark. Supply Chain Manag., vol. 2, no. 1.

Peng, Z., Shan, W., Jia, P., Yu, B., Jiang, Y., \& Yao, B. (2020) Stable ride-sharing matching for the commuters with payment design, Transportation (Amst)., vol. 47, no. 1, doi: 10.1007/s11116-018-9960-x.

Meshram, A., Choudhary, P., \& Velaga, N. R. (2020) Assessing and Modelling Perceived Safety and Comfort of Women during Ridesharing, Transportation Research Procedia, , vol. 48, doi: 10.1016/j.trpro.2020.08.233.0.

Jais, A. S., \& Marzuki, A. (2020) E-hailing services in Malaysia: Current practices and future outlook, Plan. Malaysia, vol. 18, no. 3, doi: 10.21837/PM.V18I13.780.

Valcour, M. (2015) Facilitating the crafting of sustainable careers in organizations. In V. d. Heijden, Handbook of Research on Sustainable Careers (pp. 20-34). Edward Elgar Publishing.

McDonald, K., \& Hite, L. (2018) Conceptualizing and Creating Sustainable Careers. Human Resource Development Review, Vol.17, No.4, 349-372.

Knockaert, S., \& Maillefert, M. (2004) What Is Sustainable Employment? The Example of Environmental Jobs. Nature Sciences Societies Volume 12, Issue 2, 135-145.

Rapuano, V. (2020) Toward Sustainable Careers: Literature Review. Contemporary Research on Organization Management and Administration Vol. 8 (1), 41 - 54 .

Yu, B., Ma, Y., Xue, M.-M., \& Tang, B. (2017). Environmental benefits from ridesharing: A case of Beijing. Journal of Applied Energy 191, 141-152.

Droupr Corporation. (2018). Carpooling with Droupr means you save and others can travel. Retrieved from Droupr: https://www.droupr.com/

Konrad, A. M., Ritchie, J. J., Lieb, P., \& Corrigall, E. (2000) Sex differences and similarities in job attribute preferences: a meta-analysis. Psychological Bulletin, Vol. 126, 593-641.

Hall, J. V., \& Krueger, A. B., (2016). An Analysis of the Labor Market for Uber's Driver-Partners in the United States. National Bereau of Economic Research, 3-34.

Chen, M. K., \& Sheldon, M. (2016). Dynamic Pricing in a Labor Market: Surge Pricing and Flexible Work on the Uber Platform. Proceedings of the 2016 ACM Conference on Economics and Computation (p. 455). Europe: Association for Computing Machinery.

Shokoohyara, S. (2018). Ride-sharing platforms from drivers' perspective: Evidence from Uber and Lyft drivers. International Journal of Data and Network Science 2, 89-98.

Malin, B. J., \& Chandler, C. (2016). Free to work anxiously: Splintering precarity among drivers for Uber and Lyft. Communication, Culture \& Critique, Volume 10, Issue 2, 382-400.

Janis, V., \& Ziaran, P., (2017). Motivational drivers of competitive and cooperative personalities: Implications for efficient HR management. International Journal of Organizational Leadership, 157-168.

Puteh, F., Kaliannan, M., \& Alam, N. (2016). Employee Core Competencies and Organisational Excellence: An Interpretative Analysis. Australian Journal of Business and Economic Studies, Vol. 2, No. 1, 45-53. 
Francis-Smythe, J., Haase, S., Thomas, E., \& Steele, C. (2013). Development and validation of thecareer competencies indicator (CCl). Journal of Career Assessment, Vol. 21, No. 2, 227-248.

Shove, E., Pantzar, M., \& Watson, M. (2012). The Dynamics of Social Practice - Everyday Life and how it changes. 1st ed. London: SAGE Publications Ltd.

Cass, N., \& Faulconbridge, J. (2016). Commuting practices: New insights into modal shoft from theories of social practice. Transport Policy, Volume 45, 1-14.

Bauer, D. (2017). Opportunities and barriers of ridesharing in work commuting - a case study in Sweden. Sweden: Department of Earth Sciences, Upsala University.

Robson, R., Havas, K., Ray, R., \& Robson, E. (2020). Competency Framework Development Process Report. Florida: Eduworks Corperation.

Ahmad, B., Latif, S., Bilal, A. R., \& Hai, M. (2019). The mediating role of career resilience on the relationship between career competency and career success. Asia-Pacific Journal of Business Administration 11(3), 209-231.

Naswall, K., Kuntz, J., Hodliffe, M., \& Malinen, S. (2015). Employee resilience scale (EmpRes): measurement properties. University of Canterbury, Christchurch: Resilient Organizations Research Report. .

Li, Y., \& Taeihagh, A. (2017). The governance of risks in ridesharing: Lessons learned from Singapore. 3rd International Conference on Public Policy (ICPP3), (pp. 3-24). Singapore.

Borraz, O., (2011). From risk to the government of uncertainty: the case of mobile telephony. Journal of Risk Research, 14 (8), 969-982.

Renn, O., \& Benighaus, C. (2013). Perception of technological risk: Insights from research and lessons for risk communication and management. Journal of Risk Research, 16 (3-4), 293-313.

Walker, W., Marchau, V., \& Swanson, D. (2010). Addressing deep uncertainty using adaptive policies: Introduction to section 2. Technological Forecasting \& Social Change,77, 917923.

Izham, M. I. (2018). Regulating E-Hailing In Malaysia. Is There Over-Regulation? Malaysia: Asia Pacific Legal Markets.

Taleb, N. (2012). Antifragile: Things that gain from disorder." New York: Random House Digital.

Mishra, P., \& McDonald, K. (2017). Career resilience: an integrated review of the empirical literature. Human Resource Development Review, Vol. 16, No. 3, 207-234.

Mansfield, C., Beltman, S., Price, A., \& McConney, A. (2012). Don't sweat the small stuff:understanding teacher resilience at the chalkface. Teaching and Teacher Education, Vol. 28, No. 3, 357-367.

Hair, J. F., Hult, G. T. M., Ringle, C. M., \& Sarstedt, M. (2017). A Primer on Partial Least Squares Structural Equation Modeling (PLS-SEM), Second Edi. SAGE Publications, Inc.

Urbach, N., \& Ahlemann, F. (2010). Structural Equation Modeling in Information Systems Research Using Partial Least Squares, J. Inf. Technol. theory Appl., vol. 11, no. 2, pp. 540, 201.

Fornell, C., \& Larcker, D. F. (1981). Evaluating Structural Equation Models with Observable Variables and Measurement, J. Mark. Res., vol. 18, no. 1 (Feb., 1980), pp. 39-50.

Hair, J. F., Hult, G. T. M., Ringle, C., \& Sarstedt M. (2017). A Primer on Partial Least Squares Structural Equation Modeling (PLS-SEM).," Sage, Thousand Oaks. 